\title{
A Brief Analysis on the Transfer Platform of Land Management Rights Based on Agricultural Economy
}

\author{
Dili Song, Chunmei Liang*
}

\author{
School of business, Shandong Normal University, Jinan 250300, China \\ *Corresponding author. Email: $995093262 @ q q . c o m$
}

\begin{abstract}
Fragmentary and decentralized management of agriculture is an important factor restricting the development of agriculture in our country. The establishment of land management right transfer platform is conducive to the information exchange between participants, guide and standardize the process of land transfer, and promote the healthy development of China's land transfer market. This paper learned about the current construction of land transfer platform (hereinafter referred to as the platform) through field investigation in $\mathrm{F}$ county, Shandong province. The platform has the characteristics of sharing, timeliness, hierarchy, openness and comprehensiveness, and undertakes multiple functions such as information sharing, intermediary service, transaction, docking service and statistical analysis. Relying on the Internet, the platform timely and effectively collects and releases circulation information, and its service capacity is significantly enhanced.
\end{abstract} Keywords: Land transfer platform, flow pattern, function

\section{INTRODUCTION}

It is the only way to modernize agriculture with Chinese characteristics to develop various forms of moderate scale operation, which can be realized through the transfer of land management rights. Over the past 70 years since the founding of the People's Republic of China in 1949, the reform of the land system has been deepened. According to the results of the third national agricultural census, in 2016, there were more than 3.5 million large-scale farming households with an area of more than $50 \mathrm{mu}$ and over 350 million mu of farmland. With the expansion of land circulation scale, standardizing and guiding the healthy development of land circulation market has been put on the agenda.

The promotion of land circulation has always been one of the main issues concerned by the government and scholars. Related researches focus on the significance of land circulation, the influencing factors of land circulation and the countermeasures to promote land circulation. Through empirical analysis, Mao et al. (2015) concluded that land transfer can promote the income of peasant households to different degrees. However, land circulation faces many influencing factors. From the macro level, studies on the influencing factors of farmland transfer mainly focus on the institutional design of farmland, social and economic development, farmland property rights arrangement, non-agricultural employment and rural social security development, etc. (Qian, 2002; Ye, 2010; Xu et al., 2011; Yan et al., 2013], concerning the influence of part-time employment on land circulation at the micro level. At the micro level, it involves the influence of part-time employment on land circulation, the influence of risk consciousness and risk preference on land circulation intention ( $\mathrm{Li}$ 2014), The influence of farmland endowment on farmland transfer decision-making (Li et al., 2015) and family demographic characteristics and economic characteristics on farmland transfer market(He et al.,2016). In view of the problems existing in the circulation, many scholars put forward the policy on the construction of land circulation platform. Chen xiaohua (2014), based on the scientific analysis of the basic characteristics and organizational attributes of the new business entity, proposed to establish an effective mechanism for the transfer of land elements to the new business entity and improve the three-level land transfer service system in counties and villages as the key tasks of cultivating the new business entity. Zhang et al. (2019) proposed that the construction of a network platform for rural land transfer could achieve a win-win situation among the government, the village collective and the transfer parties.

In promoting the construction of the market for the transfer of land management rights, most of them rely on rural management institutions to improve the land transfer service platform and improve the three-level service and management network in counties and villages. This paper intends to briefly analyze the land transfer platform based on the field investigation of the implementation of the transfer platform in F county, Shandong province.

\section{CASE STUDY -- TAKE COUNTY F AS AN EXAMPLE}

\subsection{The Circulation Situation}

F county of province since 2013 by the ministry of agriculture as the national land contract rights 
counterpoising truly pioneer city agencies work camp, as of May 2016, all F county, 605 administrative villages in 598 completed the approval registration agencies, involved the contracted land area of $865700 \mathrm{mu}$, the distribution of family contract, management authority card 197200, certified rate of $99 \%$ or more. The transfer area of contracted land management rights in the county reached $306,000 \mathrm{mu}$, accounting for $38 \%$ of the total land area. On the basis of the confirmation of rights, the rural economic and management department of $F$ county initially established a platform for the transfer of rural land management rights in 2016.

At present, the land circulation situation of 15 townships or streets in F county entering the land circulation platform has the following characteristics: as of March 2016, 1,561 land circulation cases had been registered on the integrated rural land circulation service platform of $\mathrm{F}$ county. The average outflow area of a farmer's household of a land supplier is between 1.52 and $2.76 \mathrm{mu}$, regardless of the unit into which it flows.

\subsection{Features and Functions of the Circulation Platform}

There are few discussions on land circulation platforms at home and abroad. Based on the background of the Internet, this paper concludes that the land circulation platform has five characteristics of sharing, timeliness, hierarchy, openness and comprehensiveness based on the investigation of grassroots practice. In addition, the platform has five functions: information sharing function, intermediary service function, transaction function, docking service function and statistical analysis function. Sharing. The platform is a public welfare platform for the participation of farmers, village collectives, land use subjects and government departments. The platform is conducive to optimizing the allocation of land, capital and labor (management) resources, improving the utilization efficiency of resources, reducing transaction costs and improving the overall social welfare.

Timeliness. On the one hand, the platform should timely collect and release land circulation information, so that the information can be timely stored and released. On the other hand, we should create conditions for farmers and land users to receive more information, carry out farmers' mobile application skills training and network training, and train professional farmers in the new era.

Hierarchy. In platform construction, county units are used to set up three levels of platform organizations, namely county, township and village. Economically backward areas can be counties and counties together to build a platform to achieve common platform.

Openness. On the one hand, the construction of circulation platform promotes circulation, on the other hand, it also has other functions. It is conducive to the docking of agricultural capital sales, agricultural machinery services, agricultural products sales and other parties, and can also lay a good foundation for the next mortgage of land management rights

Comprehensiveness. Land circulation platform includes information platform, trading platform and service platform. The trading platform promotes standardized trading and the service platform has the functions of legal consultation and dispute mediation.

According to the situation, we draw the basic functions of the platform: information sharing function, intermediary service function, transaction function, docking service function and statistical analysis function.

\section{CIRCULATION PLATFORM OPERATION AND FUNCTION}

\subsection{Flow Platform and Flow Mode of Effective Docking Process}

According to wu zhenjun et al. (2011) 's circulation mode classification method, this paper makes appropriate variations, the $\mathrm{F}$ county land management rights transfer summarized into four patterns: spontaneous flow transformation, the transformation of the mediation flow I II and market flow transformation, the mediation flow transformation, four patterns of land circulation to the platform, in different forms.

First, spontaneous flow transformation. Generally involved in the small scale of land, the scope is also mostly limited to the transfer between the village. The main difficulty of this transfer mode lies in the difficulty of information connection between farmers on the supply side and the main body of land on the demand side, as well as the high cost of negotiation and implementation.

Second, the mediation flow transition I. The characteristic of this model is that village collective plays a key role in circulation transaction, which connects the majority of farmers and the main body of land use of land managers. However, in this mode of circulation, the role of the village collective can be given full play to reduce information asymmetry and increase the collective income of the village.

Third, the mediation flow transition II. The characteristics of this circulation mode are that the village collective serves as the circulation platform at the bottom to provide coordination services for the supply and demand of land circulation, and the farmers and the subject of land use directly sign contracts. It involves four subjects, four steps and the characteristics of a flow.

Fourth, market flow transformation. This mode is characterized by the acquisition and transaction of information between the supply and demand of land circulation through the circulation platform, which saves the intermediate costs. 


\subsection{The Circulation Platform Is Beneficial to Reduce the Transaction Cost of Land Circulation}

In the process of land transfer, the main transaction costs faced by the farmers of the main supplier are information release, negotiation, contract identification and income acquisition. The main body of land use is mainly faced with transaction costs in terms of searching information, land concentration, negotiation and signing contracts, ensuring the execution of contracts and payment of benefits .With the construction and improvement of the land circulation platform based on the right confirmation, especially the transformation from the spontaneous circulation mode to the market transaction circulation mode, the transaction costs of multiple links in the land circulation process will be greatly reduced. According to the study of agricultural land transfer intermediary organization Chen et al. 2015), the platform will significantly reduce the cost of information search, negotiation and contract signing and supervision for the land use subject.

From the perspective of supply and demand, the construction of land circulation platform will promote further land circulation and improve the efficiency of resource allocation. Similarly, it is assumed that with the expansion and improvement of the functions of the land circulation platform, transaction costs of other links in the transfer of land management rights may also be further reduced, which will greatly promote the land circulation market.

\section{EXISTING PROBLEMS AND POLICY RECOMMENDATIONS}

The construction of land circulation platform is conducive to the full activation of rural market, factors and subjects, and promotes the scale operation and healthy development of rural land. Establish a sound market for the transfer of land management rights, so as to formalize the transfer of land, reduce the obstacles of land transfer and activate the vitality of land resources. After the government pays the fixed cost of establishing a land transfer market, the transaction costs of a single land transfer contract will be greatly reduced. However, in the three counties and cities investigated by the author at the beginning of 2019, the construction situation of the circulation platform is as follows: one is in preparation for construction, while the other is still under construction, and only one county has established the land circulation platform.

However, many functions of the platform have not been fully realized yet. In terms of platform construction, it was found in the survey that although the platform is under construction, there are no special government departments and personnel responsible for the construction and management of the platform, and the daily work of the platform is all completed by part-time workers. At the same time, the construction and operation of the platform needs to grasp the content of several aspects.

Firstly, the construction of circulation platform should follow the principle of government leading, market operation and public welfare service. In the construction and operation process of the circulation platform, the government should give full play to its role, with the rural operation and management departments as the starting point, to study and establish special offices and assign special staff. Platform operation should adhere to the market-oriented operation mode, in line with the purpose of providing timely and efficient services for agriculture. We will increase financial support and provide public services to benefit the people.

Secondly, we should respect the willingness of individual farmers to trade and cultivate their awareness and ability of standardized circulation. If our goal is to achieve a certain scale of land management, we should take the effect of achieving the goal as the criterion, the fundamental choice lies in the farmers. From the practice of grassroots platform, land right confirmation is the foundation of platform construction. To accelerate the high-quality completion of the work of the confirmation of rights, improve the intensity of farmers' property rights to the land through the confirmation of farmland rights. After the clarification of property rights, on the one hand, it can improve the allocation efficiency of the resource stock, on the other hand, it can bring higher income flow to the transaction subjects. In terms of income distribution, we should pay attention to the rights and interests of farmers, village collectives and the main body of land use so as to prevent infringement of farmers' interests. On the premise of adhering to the voluntary transfer of farmland, the government should play an active role in management and guidance.

Finally, we should prevent the government and the agents of collective organizations from harming the rights and interests of farmers, accelerate the reform of rural collective property rights system, and reconstruct rural collective economic organizations. The study found that the intervention of village collectives and intermediary organizations could effectively reduce the transaction costs of circulation and realize the concentration of agricultural land. Relying on the organization and coordination of the village collective, the search, negotiation and implementation costs in the land transfer are reduced.

At present, the village committee is generally responsible for the report and summary of land concentration and circulation information, and the village committee is responsible for the effective operation of the village-level circulation platform. At the same time, the village committee ACTS as an intermediary between farmers and the main body of land use. Sometimes, the village committee directly participates in the land transfer, which causes the village committee to take some risks, which conflicts with the role of the autonomous organization of the village committee. Therefore, at present, while promoting the platform construction, we should also carry out the reform of the collective property right system in 
rural areas and establish collective economic organizations to serve the work related to land circulation.

\section{REFERENCES}

[1] MAO peihua, Xu ji. Farmland system, transfer of land management rights and farmers' income growth [J]. Management world, 2015, (5): 63-74+88

[2] Qian zhonghao. Incomplete property rights of rural land contracting and management rights and market circulation dilemma: theory and policy analysis [J]. Management world, 2002 (6): 35-45+154-155

[3] Ye jianping, Feng lei, Jiang yan, Roy prosterman, zhu keliang. Survey and research on rural land use rights in China in 2008 [J]. Management world,2010 (1): 64-73

[4] Xu hengzhou, Guo yuyan. Co-integration analysis of the relationship between farmers' non-agricultural income and rural land transfer -- a case study of nanjing, jiangsu province [J]. China population. Resources and environment, 2011 (6): 61-66

[5] Yan xiaohuan, Huo xuexi. Farmer employment, rural social security and land transfer -- based on the analysis of 479 farmers in henan province [J]. Journal of agricultural technology and economy, 2013 (7): 34-44

[6] Li jinggang, Gao yanmei, Zang junmei. Influence of farmers' risk consciousness on decision-making behavior of land circulation [J]. Journal of agricultural technology and economy, 2014 (11): 21-30

[7] Li qin, li dazheng, Li chengzheng. Family farmland endowment and farmland transfer decision -- an investigation based on nonlinear relationship [J]. Zhejiang social sciences, 2015 (10): 19-28+155

[8] He xin, Jiang tao, Guo liangyan, Gan li. Development of China's farmland transfer market and rural household transfer -- based on the farmer household survey data in 29 provinces in 2015 [J]. Management world, 2016 (6): 79-89

[9] Chen xiaohua. Vigorously cultivating new agricultural management subjects -- speech at the annual meeting of China association of agricultural economics [J]. Issues of agricultural economy, 2014 (1): 4-7. 